\title{
Eventos e sua importância para a gestão da comunicação organizacional na pós-modernidade
}

Events and their importance for management of
organizational communication in post-modernity

Eventos y su importancia para la gestión de la comunicación organizacional en la posmodernidad

\section{Luiz Alberto de Farias}

- Doutor em Comunicação e Cultura pelo Programa de Pós-Graduação em Integração da América Latina, da Universidade de São Paulo (Prolam-USP)

- Mestre em Comunicação e Mercado pela Faculdade Cásper Líbero (Facásper)

- Especialista em Teoria da Comunicação e graduado em Relações Públicas pela Facásper

- Graduado em Jornalismo pela Universidade Cruzeiro do Sul

- Professor doutor da Escola de Comunicações e Artes da Universidade de São Paulo (ECA-USP)

- Diretor acadêmico das Escolas de Comunicação e Educação da Universidade Anhembi-Morumbi

- E-mail: Lafarias@usp.br

\section{Carolina Gancho}

- Especialista em Gestão Estratégica em Comunicação Organizacional e Relações Públicas pela Escola de Comunicações e Artes da Universidade de São Paulo (ECA-USP)

- Graduada em Relações Públicas pela ECA-USP

- E-mail: carolgancho@yahoo.com.br 


\section{Resumo}

Em tempos de comunicação digital e virtual, os eventos continuam sendo instrumentos valiosos de relacionamento com os públicos de interesse de uma organização. Este trabalho analisa os eventos em dois momentos históricos, a modernidade e a pós-modernidade, com o objetivo de compreender sua relevância para a gestão estratégica das relações públicas e da comunicação organizacional. Partindo da hipótese de que os eventos teriam sido ressignificados na pós-modernidade, deixando de lado seu aspecto espetacular e tornados mais estratégicos, acabou-se por concluir que o momento ainda é de transição. Apesar de a lógica indicar que os eventos poderiam ter assumido uma posição mais adequada à realidade da comunicação digital, os resultados da pesquisa mostraram que ainda há muito que caminhar na direção de uma comunicação verdadeiramente dialógica.

PALAVRAS-CHAVE: PÓS-MODERNIDADE • RELAÇÕES PÚBLICAS • COMUNICAÇÃO ORGANIZACIONAL• EVENTOS • SOCIEDADE DO ESPETÁCULO.

\section{Abstract}

In times of digital and virtual communication events continue to be valuable instruments of relationship with the publics of interest of an organization. This work analyzes the events in two historical moments, modernity and post-modernity, with the purpose of understanding their relevance for the strategic management of public relations and organizational communication. Starting from the assumption that the events had been re-signified in post-modernity, setting aside their spectacular aspect and becoming more strategic, one has ultimately concluded that the moment is still one of transition. Although logic shows that the events could have assumed a position that was more adequate for the reality of digital communication, the results of the survey proved that there is still much to go in the direction of a truly dialogical communication.

\section{KEYWORDS: POST-MODERNITY • PUBLIC RELATIONS・ORGANIZATIONAL COMMUNICATION • EVENTS・SPECTACLE SOCIETY}

\section{Resumen}

En tiempos de una comunicación digital y virtual, los eventos continúan siendo instrumentos valiosos de relacionamiento con los públicos de interés de una organización. Este trabajo analiza los eventos en dos momentos históricos, la modernidad y la posmodernidad, con el objetivo de comprender su relevancia para la gestión estratégica de las relaciones públicas y de la comunicación organizacional. Partiendo de la hipótesis de que los eventos tendrían sido resignificados en la posmodernidad, dejando de lado sus aspectos espectaculares y convertidos en más estratégicos, se acabó por concluir que el momento todavía es de transición. A pesar de que la lógica indique que los eventos podrían haber asumido una posición más adecuada a la realidad de la comunicación digital, los resultados de la investigación mostraron que todavía hay mucho para caminar en dirección de una comunicación verdaderamente dialógica. 
á muitos anos os eventos estão entre os principais instrumentos utilizados pelas organizações para relacionamento com os públicos. Décadas atrás, ao lado de ações como a assessoria de imprensa, eles foram reconhecidos por serem capazes de trazer resultados mais eficazes que ações de outras áreas da comunicação - como a publicidade tradicional - e a custos muito inferiores, ganhando, assim, espaço dentro do mix da comunicação organizacional. No cenário pós-moderno, em que predominam as relações virtuais, em detrimento da comunicação face a face, percebe-se que os eventos, diferentemente do que se poderia imaginar, ainda são instrumentos escolhidos por diversas organizações para aprofundar seus relacionamentos.

Pode-se atribuir essa preferência pelos eventos principalmente ao fato de que, ao contrário de outras atividades de comunicação, eles promovem maior relacionamento ou, para usar um termo mais adequado, engajamento com os públicos a que se destinam. Conforme afirma Roosevelt Hamam (2006, p. 130), "dificilmente qualquer outro meio de comunicação poderia atingir em cheio um público tão específico em uma só oportunidade". E é esse o grande diferencial dessa ferramenta de comunicação: ela atinge diretamente o público-alvo e é capaz, se bem planejada e realizada, de promover uma experiência única e um vínculo sem igual. Assim, faz parte da natureza dos eventos a interação com o receptor, entendendo-se por interação a transmissão de mensagens e o feedback.

Por outro lado, também faz parte da natureza dos eventos, principalmente levando-se em conta a forma como foram desenhados e planejados durante a modernidade, uma estrutura espetacular, em que prevalece a comunicação de mão única, que frequentemente coloca o público como plateia, apenas recebendo as informações, sem qualquer interação.

Apesar de em todo o discurso das relações públicas, desde seu nascimento na modernidade, de que era preciso dialogar com os públicos, construindo uma comunicação de mão dupla, não foi o que se viu na organização e realização de eventos. Ao contrário, o que se deu nesse período foi a utilização desse instrumento de forma espetacular para criar uma atmosfera que representasse a realidade e que reproduzisse discursos e valores da organização por trás dos eventos.

Se durante a modernidade o aspecto espetacular prevaleceu sobre o aspecto relacional, tendo o público sido tratado como espectador passivo e receptor de conteúdos, o que se esperava é que na pós-modernidade essa realidade tivesse mudado. Porém, o que se percebe, após uma cuidadosa análise de ambos os períodos e da forma como a organização de eventos foi tratada em cada um deles, é que a comunicação não é uma lógica matemática e a pós-modernidade é uma época que ainda está acontecendo e transformando a sociedade. Em outras palavras, o momento é de transição.

\section{UMA BREVE CONCEITUAÇÃO DE EVENTOS}

Existem diversas definições de eventos, dentre as quais citamos aqui a de Cristina Giácomo (2007, p. 40), que explica:

0 evento, como reunião política de pessoas e instrumento de comunicação, e não como sinônimo de fato, pode ser entendido como: acontecimento previamente planejado, a ocorrer num mesmo tempo e lugar, como forma de minimizar esforços de comunicação, objetivando o engajamento de pessoas a uma ideia ou ação (grifo da autora).

Assim, o primeiro ponto fundamental a ser observado em relação aos eventos é que, como qualquer atividade, precisam ser realizados de maneira planejada. Isso significa que, por trás deles, existe um processo racional-lógico que pressupõe 
não apenas a previsão de cenários, como também um estudo complexo para o estabelecimento e a adequação de objetivos, alocação de recursos, tomada de decisões e diagnósticos. Contudo, infelizmente ainda existe grande preconceito, vindo muitas vezes dos próprios profissionais de comunicação organizacional e relações públicas, que veem o evento como uma atividade fácil de ser executada e puramente operacional. Ora, a realidade do profissional de eventos é muito mais desafiadora do que se possa imaginar, seja ele o cliente (a organização que promove o evento) ou a agência contratada.

Se o primeiro ponto para o sucesso dos eventos é seu planejamento correto e detalhado, o segundo é a definição do públicoalvo e a adequação de todas as ações. A primeira observação importante a se fazer é que os diversos tipos de eventos estão relacionados ao público ao qual se destinam, entendendo-se o evento, na definição de Giácomo (2007, p. 12), "como fenômeno de dimensões políticas no campo da comunicação social praticado por uma variedade muito grande de instituições".

Nesse contexto, o próprio termo público-alvo (target) é um termo a ser superado, pois remete a ações de marketing e vendas, em que um produto é criado para determinado "público-alvo". Os públicos que participam de eventos corporativos e de relacionamento são, conforme Giácomo, "públicos de interesse", que têm necessidades específicas e cuja aceitação/participação deve ser ativa e interessada, binômio que ela descreve como "indissolúvel" para o sucesso de qualquer tipo de evento.

O público, como elemento principal a ser considerado entre os fatores estruturais comuns aos eventos, é eleito alvo na medida em que as reuniões são avaliadas erroneamente como produto, confundido com aquele que é objeto de trabalho da área do marketing e da publicidade e propaganda. Nesse caso, o público-alvo (ou target) é aquela fatia da população que se tem em mira para induzir ao consumo de bens e serviços (Giácomo, 2007, p. 54).

Isso significa que o desafio é cativar o público de interesse não por intermédio de um produto, mas de uma ideia, de valores, atrações e experiências, sempre levando em conta a possibilidade de uma real participação, interação do público presente. Assim, o evento de relacionamento e todo o sistema comunicacional dentro dele assumem uma característica diferente, porque as respostas contínuas dos receptores realimentam o processo do evento. Logo, toda a lógica do evento se reestrutura, o evento não alcança sucesso se não conseguir dialogar com o público presente.

Na era digital, as pessoas querem interagir e as organizações precisam reconhecer e possibilitar que seus públicos tenham voz ativa, aprendendo a fazê-lo de forma amigável e estando preparadas para tal exposição. Mesmo em eventos cujo objetivo é atingir mais diretamente o público consumidor, ou cliente final, deve-se ter em mente que não se deve tratá-lo de forma passiva, como mero assistente, espectador, sem reação. Tanto na publicidade, como no marketing e nas relações públicas, os públicos hoje procuram interação. É por isso que tantas empresas têm investido na criação de páginas nas redes sociais e ações que permitam o diálogo e a participação ativa de seus públicos.

\section{EVENTOS COMO FERRAMENTA DE COMUNICACX̃̃O ORGANIZACIONAL E RELAÇÕES PÚBLICAS}

Margarida Kunsch explica que a comunicação organizacional é a disciplina que se debruça sobre o fenômeno comunicacional dentro das organizações, analisando o sistema, o funcionamento e o processo de comunicação entre a organização e seus públicos de interesse. Segundo a autora, a comunicação organizacional é um "fenômeno inerente aos agrupamentos de pessoas que integram uma organização ou a ela se ligam" (Kunsch, 2003, p. 149). Defende ela o conceito da "comunicação 
organizacional integrada", que compreende a comunicação institucional, a comunicação mercadológica, a comunicação interna e a comunicação administrativa.

Roberto Porto Simões vai além do aspecto social da comunicação organizacional e explica as relações públicas também por sua função política. Segundo ele,

como ciência, relações públicas abarca o conhecimento científico que explica, prevê e controla o exercício de poder no sistema organização-públicos.Como atividade, relações públicas éo exercício da administração da função(subsistema) política organizacional, enfocado através do processo de comunicação da organização com seus públicos (Simões, 1995, p. 42 - grifo do autor).

Logo, os eventos são uma das principais ferramentas da comunicação organizacional - que abarca todos os fluxos e processos de comunicação entre a organização e seus públicos - e têm a mesma natureza das relações públicas, que visam administrar todos os tipos de interação entre a organização e seus públicos de interesse.

Assim como outras ferramentas modernas de comunicação, os eventos precisam ser organizados sob a lógica do fluxo de mão dupla com os públicos da organização. Simões (1995, p. 162) classifica os eventos como instrumentos mistos e os entende como um instrumento alinhado ao que ele considera um "objetivo essencial das relações públicas", a legitimação.

Contudo, para que esse objetivo seja alcançado, é preciso que os eventos sejam concebidos de maneira estratégica. E isso só pode acontecer, segundo Ethel Pereira (2011), se houver alinhamento entre o planejamento da organização e o planejamento específico de eventos, seguindo os princípios éticos da atividade comunicacional.

\section{EVENTOS COMO ESTRATÉGIA MODERNA DE RELAÇÕES PÚBLICAS}

As sociedades não se formam de um dia para o outro. É preciso que haja uma série de transformações estruturais que sirvam como condições para que se defina a existência de uma nova época. No caso da sociedade moderna e da pós-moderna, esse processo não é diferente, muito embora seja difícil precisar em que momento uma tenha superado a outra e dado início a uma nova era. Como afirma Domenico de Masi (1999, p. 12), "a sociedade industrial não se formou de repente, e tampouco foi ultrapassada de repente pela sociedade pós-industrial".

Esse rompimento histórico é diferente e muito mais sutil do que aconteceu em períodos mais antigos da pré-modernidade. A própria mudança do mundo feudal para a modernidade é muito mais nítida do que a chegada da pós-modernidade, com relação à modernidade. Alguns chegam mesmo a questionar se existe uma nova era ou se ainda se vive a modernidade. Logo, é preciso analisar cautelosamente os aspectos que deram origem a essas épocas e pontuar suas principais características antes de se ver de que forma impactaram a área de comunicação.

0 aspecto tecnológico introduzido durante a modernidade foi a base para toda as outras transformações que aconteceram nesse período. Do ponto de vista da fábrica e da produção, as organizações passaram a ser vistas com máquinas (Morgan, 1996), produzindo de forma rápida e em massa. A divisão do trabalho, perfeitamente ilustrada no filme Tempos modernos, de Charles Chaplin, embora tenha alienado o trabalhador do restante da produção, possibilitou ao capitalismo e aos donos do capital um crescimento vertiginoso de suas fábricas, propiciando uma margem de lucro nunca antes imaginada. A filosofia de que o tempo é dinheiro, pronunciada por Benjamin Franklin e repetida até os dias atuais, refletia o cerne da 
produção nas fábricas e apagava da história a figura do artesão, que detinha o conhecimento de todo o processo produtivo. 0 conhecimento familiar dava lugar à produção em massa, 0 artesão dava lugar ao operário alienado, as pequenas oficinas artesanais davam lugar às grandes corporações.

Recorrendo a outro filme, quem assistiu ao crítico The corporation, de Jennifer Abbott e Mark Achbar, de 2003, certamente pode ter concordado ou discordado de vários aspectos de que o filme trata, mas nunca de sua tese principal: as corporações ocupam papel central na sociedade capitalista pós-Revolução Industrial. No filme, as corporações são retratadas como vilãs, criações artificiais que visam apenas ao lucro máximo a qualquer custo, mesmo que o preço seja a destruição ambiental.

As corporações, desde a modernidade aos dias de hoje, passaram a fazer parte da sociedade e, mais que isso, são consideradas entidades personificadas. Uma corporação tem status de "pessoa jurídica".

Além da Revolução Industrial, a revolução que marcou o fim da Idade Média e serve como marco da Era Moderna foi tecnológica, mas aconteceu em outra esfera: a revolução comunicacional, iniciada com a criação da prensa gráfica por Johann Gutenberg. Diferentemente do método utilizado até aquele momento, conhecido como "impressão em bloco", que utilizava um pedaço de maneira entalhada para imprimir página a página, a criação dos tipos móveis viria a facilitar a disseminação da informação em todo o mundo.

A criação da prensa gráfica foi apenas o ponto de partida para uma revolução da comunicação que mudou as relações entre os indivíduos. A imprensa escrita, o rádio e a televisão já nasceram com características muito diferentes dos antigos meios de comunicação: foram voltados para a massa, com um alcance abrangente e homogêneo.

Nesse contexto de comunicação massificada e de expansão capitalista, surgem as relações públicas, que, na visão de Cecília Peruzzo (1986), nasceram dentro (e a serviço) do sistema de produção capitalista, em seu período mais selvagem. As relações públicas, na modernidade, infelizmente não conseguiram, ou pouco conseguiram, agir conforme seus princípios de administrar a comunicação com os seus públicos de interesse, uma vez que a comunicação não existia. 0 fluxo de comunicação era de mão única, dentro da lógica de apenas informar e disseminar discursos interessantes à organização.

Dentre tantos críticos da modernidade, um dos mais fervorosos e intrigantes é, sem dúvida, o francês Guy Debord. Em 1967, ele publicou o livro A sociedade do espetáculo, com um texto denso, porém lúcido, no qual afirma que a sociedade moderna teria se transformado em um grande espetáculo, objeto de contemplação. Assim, longe de ser apenas uma forma de intermediação, o espetáculo atinge todos os aspectos da vida em sociedade, ele é a sociedade moderna.

Toda a vida das sociedades em que dominam as condições modernas de produção aparece como uma imensa acumulação de espetáculos. Tudo o que era vivido diretamente tornou-se uma representação (Debord, 2000, p. 13 - grifo do autor).

É importante esclarecer que o espetáculo ao qual Debord se refere ultrapassa o sentido do dicionário, em que tudo é espetacular, escandaloso, em que tudo é manchete, tudo é primeira página. Seu espetáculo vai além e em outra direção dessa primeira leitura, pois é muito mais abrangente, muito mais fundamental, muito mais causa do que efeito, muito mais entranhado na vida social, em suas condições modernas de produção, do que se supõe no primeiro momento.

Para ele, o espetáculo não pode ser tomado apenas sob o aspecto dos meios de comunicação de massa, que são sua manifestação superficial mais esmagadora, porque essa simplificação restringiria a crítica à pura instrumentação, 
quando, na verdade, tal instrumentação nada tem de neutra ou simples, uma vez que ela convém à sobrevivência dessa sociedade. Para isso, a própria realidade ter-se-ia tornado objeto de contemplação. Debord (2000, p. 30) escreve que "0 espetáculo está em toda parte".

Enquanto Marx mostrou a transformação da sociedade em mercadoria, Debord mostra a transformação da sociedade em um espetáculo. Nesse sentido, a história tornou-se mero espetáculo, mero artifício nas mãos de quem detém o poder, podendo ser utilizada sem lógica, sem passado, sem consequência.

De forma simplificada e menos crítica, Ethel Pereira (2005, p. 4) explica:

O espetáculo, ou seja, a valorização das imagens (como representação visual e mental) vinculadas às mercadorias, por meio das quais as relações de consumo são mediadas, está presente na vida cotidiana e diz respeito ao que os meios de comunicação produzem: por meio do cinema, da propaganda, da notícia, dos eventos e de programas televisivos, tais como noticiários, telenovelas e programas de auditório, entre outros, cria-se uma experiência que antecede a vivência real.

Os espetáculos são produzidos pelos meios de comunicação e fazem parte da rotina da sociedade moderna. Eles constituem uma representação da vida real em todos os seus sentidos.

Não é à toa que os eventos constituem uma das mais antigas e importantes estratégias de comunicação organizacional e de relacionamento com os públicos de interesse. Eles já nasceram como um instrumento realizado dentro de uma lógica do espetáculo, em que um ambiente é criado, artificialmente, para exposição de conteúdos e entretenimento do interlocutor. Escreve Pereira (2005, p. 3):

Os eventos simbolizam o processo de espetacularização dos negócios na sociedade contemporânea - marcada pela globalização e caracterizada pela valorização do consumo. Consequentemente, contribuem para a construção do discurso empresarial e para o fortalecimento de marcas.

Outros autores se referem a eventos como momentos espetaculares na era moderna, chegando a se referir aos participantes como "plateia":

0 gerente de eventos precisa estar ciente das necessidades da plateia. Dentre elas, podemos citar suas necessidades físicas, bem como suas necessidades de conforto, segurança e integridade física. Além desses requisitos básicos, há a necessidade de tornar o evento especial - de tocar as emoções. 0 gerente de eventos fará o possível para tornar os eventos significativos, mágicos e memoráveis (Allen et al., 2003, p. 32).

Não há como negar que o espetáculo é inerente aos eventos. Isso seria negar a própria natureza desse instrumento de comunicação. Apenas ressalta-se a importância de que se perceba essa característica e a lógica sob a qual os eventos foram constituídos na Modernidade. Segundo Francisco E. Ponte Pierre (apud Simões, 1995, p. 170),

0 evento busca fortalecer a imagem através de um ato. Ele procura sacralizar um poder que nos ama, uma providência que zela por nós, uma racionalidade superior. Melhor que um ato, o evento insere-se na categoria de celebração religiosa (....). Com seu caráter tribal, o evento solidifica vínculos, realiza a fusão que só a crença proporciona.

Eventos são aqui definidos como ritos, comparados a uma celebração religiosa. Apesar de parecer exagerada, a alegoria é correta à medida que, assim como em tais acontecimentos, os eventos reúnem, em um mesmo espaço e local, pessoas que buscam o mesmo interesse e que passam por um momento espetacular, sendo submetidas a um conteúdo previamente 
programado. Como se unidos por uma crença, os participantes e os organizadores, no caso as empresas, podem, por meio desse "ato", solidificar vínculos, aprofundar relacionamentos e viver uma experiência única.

\section{ORGANIZAÇÃO DE EVENTOS: INSTRUMENTO DE RELACIONAMENTO RESSIGNIFICADO NA ERA PÓS-MODERNA}

0 mundo de hoje não vive mais na era moderna. Ainda que alguns dos elementos fundamentais desta estejam presentes, uma série de transformações, sobretudo políticas, sociais e tecnológicas, faz com que muitos autores creiam estarmos vivendo em uma nova época.

O ponto de partida para o estudo da pós-modernidade é a compreensão de que, embora haja semelhanças com a modernidade, não há como negar que são épocas distintas, uma vez que algumas mudanças estruturais introduziram uma nova era na história. Para entender quais são essas transformações fundamentais, estudar-se-á a seguir também o aspecto político/ econômico, refletido na mudança nas relações de produção e de poder, bem como o aspecto tecnológico, com o advento dos meios de comunicação digitais.

O que mudou nas relações de produção não deve ser compreendido como algo radical, afinal o modo de produção capitalista prevalece e, mais do que nunca, ampliado e tornado global, adquiriu status de eternidade, de modo que parece impossível imaginar a vida em sociedade com outro modo de produção que não o capitalista. Diferentemente de outras épocas, em que o capitalismo foi colocado em cheque, atualmente as estruturas desse sistema econômico parecem ter fincando raízes definitivas na história das civilizações. Se isso é verdade ou não, o fato é que a oposição a esse sistema perdeu forças e já não se fala mais em destruição do capitalismo, mas em reforma e em melhorias.

Se o capitalismo segue como o modo de produção da sociedade atual, que determina não só a economia como as relações de poder, o que é novo? Pode-se dizer que nova é a maneira como o capitalismo global foi construído: por meio da tecnologia digital.

A globalização do sistema capitalista não é apenas a economia feita em escala global, como também está relacionada à expansão e ao fortalecimento do capitalismo como modo de produção característico do século XXI. Seja para sobreviverem e saírem de sua situação de marginalidade, seja por qualquer outro motivo, países como Cuba e China estão, paulatinamente, abrindo suas economias. Assim como esses dois países, percebe-se uma tendência mundial ao capitalismo e à inserção no "jogo da globalização".

Octávio lanni (2003, p. 143) descreve que as novas tecnologias introduzem uma nova figura que representa o poder na pósmodernidade: o príncipe eletrônico. Segundo ele, na época da globalização,

As tecnologias eletrônicas, informáticas e cibernéticas impregnam crescente e generalizadamente todas as esferas da sociedade nacional e mundial; e de modo particularmente acentuado as estruturas de poder, as tecnoestruturas, os think-tanks, os lobbies, as organizações multilaterais e as corporações transnacionais, sem esquecer as corporações da mídia. Esse pode ser o clima em que se forma, impõe e sobrepõe. 0 príncipe eletrônico, sem o qual seria difícil compreender a teoria e a prática da política na época da globalização. 
Dessa forma, embora o modo de produção permaneça o mesmo, as relações de poder mudam. Da mesma forma como na modernidade, economia, política e tecnologia caminham juntas para a formação dessa nova sociedade. Assim, mais do que dizer que as tecnologias são o meio para disseminar o sistema, fortalecendo o discurso da globalização, as tecnologias estão na base de todas as mudanças que originaram a pós-modernidade. 0 que torna o fenômeno especialmente particular é a velocidade, jamais vista, da modernização dessas tecnologias e também da circulação de informações. Todo o modo de produção foi modificado com a chegada das novas tecnologias, a que Muniz Sodré (2003, p. 23) dá o nome de integradoras:

Tais "tecnologias integradoras" apoiam e coincidem, em termos econômicos, com a extraordinária aceleração da expansão do capital (o "turbocapitalismo"), esse processo de transnacionalização do sistema produtivo e atualização do velho liberalismo de Adam Smith a que se vem chamando de "globalização" e cuja autopropaganda, atravessada pela ideologia do pensamento único, the atribui poderes universais de uniformização.

As "tecnologias integradoras" devem ser entendidas como 0 grande diferencial da pós-modernidade, pois são o fio que interliga todas as demais mudanças que delimitam esse momento histórico. As novas tecnologias, especialmente a internet, tornaram possível a globalização de fato, já que interligam todo o mundo em rede. Segundo Manuel Castells (2003, p. 255),

internet é o tecido de nossas vidas neste momento. Não é futuro. É presente. Internet é um meio para tudo, que interage com o conjunto da sociedade (...). Sem dúvida, essa tecnologia é mais do que uma tecnologia. É um meio de comunicação, de interação e de organização social.

Como teria sido possível a globalização sem a internet? Difícil imaginar. Sem as novas tecnologias, a relação entre os sujeitos não seria tão mediada, ou tão virtual, quanto vemos nos dias atuais, processo iniciado com o advento dos meios de comunicação de massa e acentuado com os meios digitais.

A comunicação entre os indivíduos caminha cada vez mais para a virtualidade, com a introdução de novos meios. Evolução do telefone tradicional, o telefone móvel (celular) permite conectar pessoas a qualquer horário, em qualquer lugar e em qualquer parte do mundo. A tradicional carta também ganhou um novo status: o e-mail, que pode ser acessado pelo tablet, pelo celular ou pelo laptop (com o auxílio do wireless, a internet sem fio ou ainda da internet móvel, 3G, 4G...) a qualquer hora e lugar. De forma ainda mais ágil, as mensagens de texto, ou a comunicação instantânea, por meio do WhatsApp ou do Facebook Messenger são ferramentas que tornam a comunicação mais virtual e menos real, pessoal e face a face. Enfim, há uma infinidade de formas novas de comunicação, que dialogam e interagem com as antigas e que tornam a comunicação cada vez mais intermediada.

Castells (2003), em seus estudos sobre a chamada era digital, apresenta dados de diferentes pesquisadores que mostram que o uso de meios digitais, em geral, não substitui outras formas de interação social, sobretudo a face a face. Após analisar diferentes linhas de pesquisa, ele conclui:

Portanto, de modo geral, o corpo de dados não sustenta a tese de que o uso da internet leva a menor interação social e maior isolamento social. Há alguns indícios, porém, de que, sob certas circunstâncias, o uso da internet pode servir como substituto para outras atividades sociais (Castells, 2003, p. 102).

Apesar de nem sempre substituírem a comunicação face a face, não há como negar que os meios de comunicação digitais são capazes de romper fronteiras e integrar as pessoas em todo o mundo, como nunca antes foi possível. Dessa forma, muito da dinamicidade da vida social pós-moderna deriva da separação de tempo e espaço, introduzida pelas novas tecnologias e pela maneira como os indivíduos se relacionam com elas e entre si. 
Diante desse novo cenário, em que os públicos não somente interagem por meio dos veículos de comunicação, mas passam a agir sobre eles, as relações públicas precisam entender que não se pode mais pensar com a lógica do espetáculo moderno.

Nem os profissionais de relações públicas nem a mídia conseguem criar as poderosas impressões que são frequentemente chamadas de "imagens'". Imagens nada mais são do que aquilo que as pessoas pensam, e a maior parte delas pensam por si mesmas, construindo suas próprias opiniões e as suas próprias imagens sobre as organizações (Grunig, 2009, p. 19).

Assim, é preciso perceber que o falso controle, que se acreditava ser possível durante a sociedade industrial, sobre a forma como as informações divulgadas eram recebidas, já não é mais conseguido na pós-modernidade. Juntamente com o discurso oficial das organizações, há uma imensidão de mensagens disseminadas diariamente que rondam a mente dos diversos públicos e que compõem a imagem que eles têm das organizações. E essa imagem é cada vez mais difícil de ser controlada e definida com precisão. Na introdução de seu livro Relações públicas estratégicas: técnicas, conceitos e instrumentos, Luiz Alberto Farias propõe uma reflexão sobre o que se entende por comunicação.

Afinal de contas, por qual boca falam as organizações? Por quais ouvidos elas recebem informações para que se posicionem de um ou de outro modo? Dentre as muitas metáforas que se aplicam às organizações de todo tipo - e têm sido utilizadas para entender os processos organizacionais -, é muito mais comum associar a comunicação ao ato da enunciação do que à capacidade de escuta e de percepção (Farias, 2011, p. 15).

Se durante a modernidade a comunicação foi centralizada em quem estava falando, talvez realmente a pós-modernidade deva se focar em quem está recebendo e de que forma isso está sendo ouvido, aceitando, verdadeiramente, um feedback, uma resposta, para constituir uma conversa, um relacionamento de fato. Em um mundo cheio de informações e de marcas, talvez seja preciso ir além da informação, ir para o campo do diálogo e da experiência. De certa forma, poder-se-ia dizer que as relações públicas vivem, na era digital, uma nova época, definida pela necessidade de incluir o público ("the public be included'). Obviamente o termo não consta nos manuais renomados de relações públicas; ele é uma reflexão sobre o novo papel do comunicador na pós-modernidade.

Sair do monólogo para o diálogo é um desafio que todos os profissionais de relações públicas deverão enfrentar e que perpassa todas as atividades de comunicação organizacional. Com os eventos, isso não é, e nem poderia ser, diferente. Ao contrário, as transformações na sociedade, que provocam uma mudança na comunicação, podem se constituir em uma oportunidade para que os eventos sejam realizados segundo uma lógica mais experiencial e participativa.

Allen et al., em seu livro Organização e gestão de eventos, mostram a relação entre as mudanças tecnológicas e a mudança nos perfis dos eventos. Eles resumem: "Uma das certezas sobre o futuro da tecnologia em eventos especiais e festivais é de que ela irá mudar - a tecnologia irá mudar, assim como a forma de gerenciar e negociar os eventos (Allen et al., 2003, p. 235).

Os autores explicam a necessidade de os organizadores e parceiros de eventos entenderem o impacto da tecnologia sobre os eventos. Hoje já se sabe que o advento dos meios digitais não tornou a comunicação totalmente virtual: meios de comunicação de massa convivem com os meios digitais e a comunicação face a face não foi extinguida, apesar de muitas vezes dar lugar à comunicação mediada. No entanto, ao contrário de como foi no passado, a comunicação face a face, ou, como Allen et al. a denominam, a "experiência real", muitas vezes não é necessária, no sentido de ser imprescindível. Há situações em que outros meios podem facilmente substituí-la, sempre em busca de maior agilidade em uma época em que o tempo é cada vez mais escasso. Assim, as organizações devem ter em mente que os públicos não precisam mais ir a eventos para buscar informações sobre a empresa, podendo eles conseguir de outras formas. 0 atrativo para o evento deve ser outro: buscar a verdadeira interação com o público presente, promovendo uma experiência diferente e um diálogo. 
O "novo marketing", como Regis McKenna o define, segundo Maria Cecilia Giaclagia (2004, p. 13), "exige a existência de um ciclo de feedback. este é elemento que está sendo deixado de lado na propaganda em monólogo, mas que é parte integrante do diálogo do marketing".

0 chamado "ciclo de feedback" é o centro da mudança do perfil dos eventos e da comunicação como um todo na PósModernidade. Mais uma vez, feedback envolve ouvir e não apenas falar, como salientou Luiz Alberto Farias anteriormente. As organizações precisam perder o costume de somente falar e aprender a ouvir, pois, afinal, tudo o que é feito por elas é designado aos seus públicos estratégicos, sendo, portanto, necessário saber a opinião dos mesmos, inclusive para entender a efetividade da mensagem ou do produto.

Obviamente que a mudança do processo de falar para ouvir não é fácil para as organizações, não apenas porque historicamente elas sempre estiveram no campo da enunciação, mas porque ouvir é também expor a organização a críticas, é sair da situação de conforto em que se controla todo o processo de comunicação. Carolina Terra (2011, p. 264) fala justamente da exposição que os novos meios impõem às organizações:

O surgimento de novos meios, como mensagens de celular, blogs e comunidades virtuais, entre outros, provoca nos profissionais de comunicação uma dupla inquietação: por um lado, abre oportunidades para exposição institucional para as organizações; por outro, deixa-as muito vulneráveis. Gerir essa dupla consequência é um dos grandes desafios dos profissionais de comunicação, demandando, também, uma especialização e entendimento no meio.

Uma forma interessante para diminuir os riscos envolvidos é elaborar uma comunicação digital alinhada com as demais comunicações, ou seja, segundo o conceito da comunicação integrada. Além disso, conforme expõe Terra, é preciso fazê-la de forma planejada, para minimizar imprevistos e ter maior controle dos resultados.

O uso de meios de comunicação digital, seja em eventos, seja na comunicação de maneira geral, pode ser bastante positivo para as organizações que querem aprofundar o relacionamento com seus públicos. Para Terra, esses meios já nascem com a característica de possibilitarem interação e feedback, segundo o modelo de uma comunicação de mão dupla. Especialmente as mídias sociais, que já nascem no formato de conversação e não de monólogo, possibilitam a comunicação dirigida diretamente ao público que se quer alcançar. Em um evento, esse processo se intensifica, uma vez que já está reunido em um mesmo espaço de tempo e lugar o público que se quer atingir.

Algumas empresas já estão colocando em prática a interação com os públicos presentes durante um evento, chamando-os a participar e dar opiniões por meio de mídias sociais, mensagens de texto, bluetooth ou aparelhos para fazer ou responder perguntas. Há quem tenha substituído o tradicional questionário de avaliação por uma mensuração de resultados em tempo real, em que o participante é convidado a responder, por meio de um aparelho, diversas questões relacionadas ao evento, tanto do ponto de vista operacional da organização, quanto do objetivo estratégico do evento (conteúdo, experiência etc.). "O mundo das relações públicas pode mostrar liderança neste novo papel como receptores poderosos, uma força que pode ouvir e auxiliar marcas a interagir e se engajar com seus clientes como nunca aconteceu antes (Terra, 2011, p. 270).

No entanto, é importante ter em mente que a mera presença desses elementos não garante, necessariamente, uma comunicação dialógica como a que está presente no ideário das relações públicas. Como é possível assegurar que a presença de elementos interativos, o uso de meios digitais e a mobilização de determinados públicos não sejam apenas novas formas de ampliar a alienação? Se forem novas formas, talvez essa seja a resposta para que eventos continuem tendo sucesso 
na pós-modernidade: os elementos mudaram, mas a construção espetacular, alienadora e de mão única prevalecem. $E$, nesse sentido, as organizações têm uma sensação maior de sucesso: conseguem reunir bons públicos e criam meios para a participação destes, ainda que essa participação seja frágil e pouco interesse às organizações, que não parecem querer dialogar com seus públicos.

No âmbito das relações públicas, atividade inserida no campo das ciências sociais aplicadas, assim como na sociedade, a tendência de transição para a pós-modernidade é percebida, mas parece seguir os passos do macroambiente, rumando para a alienação dos públicos, agora iludidos com a falsa percepção de participação, com falsos e frágeis relacionamentos.

Apesar de a sociedade do espetáculo ter sido definida na modernidade e remeter à espetacularização promovida pelos meios de comunicação de massa nesse período, o espetáculo como forma de entretenimento popular é muito mais antigo e remonta aos tempos da política do pão e circo, em Roma. No entanto, foi durante a modernidade que o espetáculo teve suas características ampliadas e globalizadas e se tornou, segundo Debord, a própria sociedade.

0 que preocupa é que a lógica espetacular, durante a pós-modernidade, parece continuar permeando a construção dos eventos com os mesmos objetivos de antes, não trazendo as rupturas que imaginávamos que ela pudesse trazer, como a democratização, a participação real, o diálogo.

Se compararmos friamente a lógica da organização de eventos na modernidade e pós-modernidade (Tabela 1), veremos que, ao contrário do que se imaginava, encontraremos mais semelhanças que diferenças.

Tabela 1 - Lógica da organização de eventos.

\begin{tabular}{|c|c|c|}
\hline EVENTOS & MODERNIDADE & PÓS-MODERNIDADE \\
\hline Responsabilidade & $\begin{array}{l}\text { Profissionais de comunicação, } \\
\text { marketing ou áreas afins }\end{array}$ & Profissionais de comunicação, Marketing ou áreas afins \\
\hline Tipo de comunicação & Face a face e de mão única & Face a face virtual e de mão única \\
\hline Estrutura & $\begin{array}{l}\text { Espetacularizada (sujeito fala e } \\
\text { "plateia" escuta passivamente) }\end{array}$ & $\begin{array}{l}\text { Espetacularizada (sujeito fala e "plateia" escuta } \\
\text { com alguns momentos isolados de interação) }\end{array}$ \\
\hline $\begin{array}{l}\text { Meios de comunicação } \\
\text { utilizados }\end{array}$ & Meios de comunicação de massa & Meios de comunicação de massa/digitais \\
\hline Interatividade & Nula ou rara & Acontece em momentos isolados \\
\hline $\begin{array}{l}\text { Motivo para a } \\
\text { realização do evento }\end{array}$ & $\begin{array}{l}\text { De acordo com a lógica da organização } \\
\text { (normalmente para transmitir alguma } \\
\text { informação nova ao público-alvo) }\end{array}$ & $\begin{array}{l}\text { De acordo com a lógica da organização (normalmente } \\
\text { para transmitir alguma informação nova ao público-alvo). } \\
\text { Em raros momentos a estratégia da realização do evento } \\
\text { é alinhada às expectativas do público ao qual se destina. }\end{array}$ \\
\hline
\end{tabular}

Apesar de ser uma comparação bastante simplista e, que fique claro, baseada em eventos corporativos e de relacionamento com públicos de interesse (e não demais tipos de públicos), ela é válida no sentido de que mostra que os eventos na modernidade e na pós-modernidade têm mais em comum do que se poderia supor. 
Na pós-modernidade, os eventos não perdem seu aspecto espetacular, pois este pertence à natureza desse instrumeto de comunicação, mas poderiam ser feitos de outra maneira. A construção e a lógica dos eventos sempre serão espetacularizados, mas isso não significa que os eventos sempre seguirão as características da modernidade. A construção do evento como um acontecimento espetacular não precisa resultar, necessariamente, em uma comunicação de mão única e autocrática. Por que não tornar o espetáculo um momento de participação? Por que não fazer com que os eventos sejam apenas momentos de divulgação de informações e propagação de discursos institucionais, para serem também um momento de interação com públicos de interesse? Acreditamos firmemente que seja possível seguir esse caminho de diálogo, humanizar o espectador, convidá-lo à participação ativa e considerar sua opinião. Essas medidas se constituem em importantes diferenciais dos eventos na pós-modernidade, capazes de trazer ainda mais sucesso para as organizações e reforçar sua imagem no sentido da transparência e do diálogo.

Assim como está na natureza dos eventos serem construídos como espetáculos, está na natureza de qualquer instrumento de comunicação promover interação e possibilitar o feedback. Logo, é preciso que as organizações contemporâneas abram espaço à participação do público em seus espetáculos, promovam o diálogo. Para que isso possa acontecer, além de a organização produtora do evento estar aberta a essa participação - condição obrigatória -, o primeiro aspecto fundamental é a escolha de um público verdadeiramente interessado no evento que se promove. 0 interesse do público em comparecer ao evento deve ser o mesmo que a organização tem pelo público presente.

Esse vínculo entre a organização e seu público deve ser sólido o suficiente para que o objetivo do evento seja alcançado e para que a interação aconteça e beneficie ambas as partes - organização e públicos. Não é possível ter sucesso em um evento cujo atrativo é, por exemplo, apenas o coquetel que será oferecido, a menos que a organização produtora do evento seja do ramo de alimentos e bebidas. Estabelecer um vínculo forte depende do atrativo que leva as pessoas ao evento e é uma atribuição da organização que o promove. Se não há um motivo realmente importante e interessante para organizar um evento, melhor não seguir por esse caminho e investir em outra ação de comunicação. 0 problema é que os profissionais responsáveis pela gestão da comunicação muitas vezes seguem orientações do corpo diretivo da organização, que ainda parece estar acostumado a ambientes pouco democráticos e participativos e que tem a inovação apenas no discurso e não na prática.

Dessa forma, faz parte da etapa de planejamento dos eventos entender a complexidade da definição do público de interesse (termo mais adequado do que "público-alvo", que enxerga o público como consumidor, alvo de um produto) e também organizar uma programação que seja atrativa para ele. Todo evento bem-sucedido passa por um planejamento rigidamente executado, levando em conta uma previsão de cenários para minimizar erros e detalhando todas as etapas de modo a garantir mais excelência durante o acontecimento. Assim, o pré-evento torna-se tão ou mais importante que o evento em si, pois ele é a base para o sucesso do evento: a correta definição da programação, a escolha e o treinamento de toda a equipe organizadora envolvida, a definição de data e local, o uso de equipamentos adequados, entre tantas outras variáveis capazes de influenciar o resultado final.

Apesar da complexidade implicada em todas as etapas da organização de eventos, é lamentável que alguns profissionais da própria área de comunicação nas organizações, e também de áreas afins, ainda tenham preconceito com relação aos organizadores de eventos, cujo trabalho é classificado como meramente operacional. Assim como qualquer outra atividade de comunicação, se feitos de forma puramente operacional e sem estar alinhados à estratégia da organização, 
os eventos podem ser pouco eficientes ou até mesmo ter resultados devastadores para a imagem da organização. Mas, ao contrário do que muitos pensam, há muita estratégia por detrás da organização de eventos, há muito mais por detrás de um palco, de um coquetel, de um palestrante.

Percebemos que a organização de eventos caminha cada vez mais, juntamente com outras atividades de comunicação organizacional e relações públicas, para o caminho da profissionalização e da estratégia. Cabe aos profissionais que fazem a gestão da comunicação a difícil tarefa de reafirmar o aspecto estratégico do trabalho que realizamos e ir além do que foi feito até agora para, de fato, construir uma comunicação de mão dupla. Mais do que simplesmente perceber elementos pósmodernos que remetem à interação, ao engajamento, à mobilização, os eventos ganham importância como aliados valiosos das organizações que querem estreitar o relacionamento com seus públicos de interesse e reforçar a imagem da marca. Os resultados que eventos podem trazer, sejam eles de pequeno ou de grande porte, têm sido apreciados pelo corpo diretivo das organizações e espera-se que, aos poucos, se dissolvam preconceitos injustificados.

Podemos, portanto, afirmar que os eventos não apenas continuam sendo importantes instrumentos para a comunicação na era digital, como, também, têm evoluído juntamente com as transformações da sociedade e estão sendo organizados de forma cada vez mais estratégica. Em outras palavras, com base no estudo teórico e prático realizado neste trabalho, percebemos que, de fato, os eventos foram ressignificados na pós-modernidade, não apenas pela inclusão de elementos de uma comunicação mais participativa e dialógica, mas também pela profissionalização e pela importância que ganharam no cenário da gestão da comunicação organizacional como ferramenta relevante e eficaz para o relacionamento com os públicos de interesse.

O fato de as relações estarem se tornando cada vez mais mediadas e virtuais não elimina a verdade de que o ser humano ainda tem relações pessoais e precisa de contato físico. Mais do que isso, as pessoas buscam ter experiências diferentes e têm, cada vez mais, o desejo e a necessidade de participar ativamente de fóruns, discussões, grupos sociais, atividades voluntárias etc., seja pessoalmente, seja de forma virtual. Há quem diga que os meio digitais estimularam esse comportamento de interação, mas talvez elas tenham apenas atendido a uma necessidade latente que a sociedade pós-moderna tenha e que foi capaz de colocar em prática por meio desses veículos de comunicação.

É preciso, finalmente, incluir os públicos de interesse nas ações de comunicação, fazê-los participar, falar e serem ouvidos, engajá-los, mobilizá-los, deixar que sejam também os protagonistas. Que instrumento melhor do que os eventos, os quais reúnem em um mesmo espaço e local o público com o qual nos queremos relacionar, para alcançar tal grau de interação? Fica aqui o convite para que, realmente, possamos colocar em prática as relações públicas em seu sentido mais genuíno e, finalmente, tentar nos relacionar com nossos públicos, realizando a comunicação de forma completa: falando e ouvindo.

\section{REFERÊNCIAS}

ALLEN, Johnny et al. Organização e gestão de eventos. 3. reimpr. Rio de Janeiro: Elsevier, 2003.

BARROS FILHO, Clóvis. Ética na comunicação. São Paulo: Summus, 2003.

CASTELLS, Manuel. A galáxia da internet. Jorge Zahar: Rio de Janeiro, 2003. Internet e sociedade em rede. In: MORAES, Denis de (Org.). Por uma outra comunicação. Rio de Janeiro: Record, 2003. 
DEBORD, Guy. A sociedade do espetáculo. [1967]. Trad. de Estela dos Santos Abreu. Rio de Janeiro: Contraponto, 2000.

DE MASI, Domenico. A sociedade pós-industrial. São Paulo: Senac, 1999.

FARIAS, Luiz Alberto de. Relações públicas estratégicas: técnicas, conceitos e instrumentos. São Paulo, Summus, 2011.

GIACLAGIA, Maria Cecília. Organização de eventos. teoria e prática. São Paulo: Pioneira Thomson Learning, 2004.

GIÁCOMO, Cristina. Tudo acaba em festa: evento, líder de opinião, motivação e público. São Paulo: Summus, 2007.

GRUNIG, James E. Definição e posicionamento de relações públicas. In: GRUNIG, James E. et al. Relações públicas: teoria, conceito e relacionamentos. 1. ed. São Caetano do Sul, SP: Difusão Editora, 2009.

GRUNIG, James E. et al. Relações públicas: teoria, conceito e relacionamentos. 1. ed. São Caetano do Sul, SP: Difusão Editora, 2009.

HAMAM, Roosevelt. 0 evento integrando o mix da comunicação. In: KUNSCH, Margarida Maria Krohling (Org). Obtendo resultados com relações públicas. 2. ed. - rev. e atualizada. São Paulo: Pioneira Thomson Learning, 2006.

HOBSBAWM, Eric. A era dos extremos: o breve século XX: 1914-1991. São Paulo: Companhia das Letras, 1995.

IANNI, Octávio. Enigmas da modernidade-mundo. Rio de Janeiro: Civilização Brasileira, 2003.

KUNSCH, Margarida M. Krohling. Planejamento de relações públicas na comunicação integrada. 4. ed. - rev., atual. e ampl. São Paulo: Summus, 2003.

MORGAN, Gareth. Imagens da organização. São Paulo: Atlas, 1996.

PEREIRA, Ethel Shiraishi. Eventos em relações públicas: ferramenta ou estratégia? In: FARIAS, Luiz Alberto de. Relações públicas estratégicas: técnicas, conceitos e instrumentos. São Paulo: Summus, 2011.

Eventos estratégicos no composto da comunicação integrada: marketing e relações públicas no fortalecimento de marcas. In: CONGRESSO BRASILEIRO DE CIÊNCIAS DA COMUNICAÇÃO, XXVIII, Rio de Janeiro, 5 a 9 de setembro de 2005. Anais... São Paulo: Intercom, 2005.

PERUZZO, Cicilia M. Krohling. Relações públicas no modo de produção capitalista. 2. ed. São Paulo: Summus, 1986.

SIMÕES, Roberto Porto. Relações públicas: função política. 3. ed. - rev. e ampl. São Paulo: Summus, 1995.

SODRÉ, Muniz. 0 globalismo como neobárbarie. In: MORAES, Denis de (Org.). Por uma outra comunicação. Rio de Janeiro: Record, 2003.

TERRA, Carolina. Relações públicas na era dos megafones digitais. In FARIAS, Luiz Alberto de (Org.). Relações públicas estratégicas: técnicas, conceitos e instrumentos. São Paulo, Summus, 2011.

Artigo recebido em 15.05.2014 e aprovado em 16.06.2014. 